DigitALCOMMONS @WAYNESTATE -

\section{Michigan Journal of Counseling: Research, Theory and Practice}

Volume $30 \mid$ Issue 1

Article 5

$2-1-2002$

\title{
Creating Partnerships: A Key Counselor Capability
}

Jean Sunde Peterson

Purdue University, jeanp@purdue.edu

John M. Littrell

jlittrel@iastate.edu

Follow this and additional works at: https://digitalcommons.wayne.edu/mijoc

\section{Recommended Citation}

Peterson, J. S., \& Littrell, J. M. (2002). Creating Partnerships: A Key Counselor Capability, Dimensions of Counseling, 30(1), 22-26. doi: $10.22237 / \mathrm{mijoc} / 1012521840$

This Article is brought to you for free and open access by the Open Access Journals at DigitalCommons@WayneState. It has been accepted for inclusion in Michigan Journal of Counseling: Research, Theory and Practice by an authorized editor of DigitalCommons@WayneState. 


\section{Creating Partnerships: A Key Counselor Capability}

\section{Cover Page Footnote}

We extend a special thanks to Claudia Vangstad for allowing us to chronicle many aspects of her work as an elementary school counselor. We also thank the administrators, faculty, staff, and students of the elementary school, as well as school board members and community leaders, for their generous cooperation during interviews. 


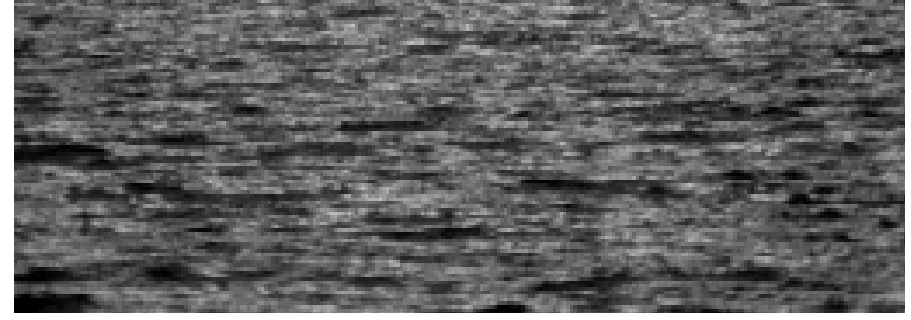

\section{Creating Partnerships: A Key Counselor Capability}

Jean Sunde Peterson

Purdue University

\section{John M. Littrell}

lowa State University

\section{Contact Information:}

$\begin{array}{ll}\text { Dr. Jean S. Peterson } & \text { Dr. John M. Littrell } \\ \text { Dept. of Educational Studies } & \text { N221 Lagomarcino Hall } \\ \text { 1446 LAEB, Room 5108 } & \text { Counselor Education, Dept. ELPS } \\ \text { Purdue University } & \text { lowa State University } \\ \text { West Lafayette, IN 47907 } & \text { Ames, IA 50011 } \\ \text { Email: jeanp@purdue.edu } & \text { Email: lilitrel@iastate.edu }\end{array}$

Counselors who create active partnerships as they implement counseling programs ensure support for their work. This ethnographic case study of an exemplary elementary school counselor details three strategies used in creating partnerships.
I solated counselors ensure that their programs will fail. Counselors engaged in active partnerships create an insurance policy to protect, support, and enhance counseling programs. Several years ago, an elementary school counselor quietly came to our attention. She had been a catalyst for school transformation, changing her hardscrabble K-5 school from a negative, punitive, violent place into a positive, harmonious place of learning (Peterson \& Littrell, 2000). Among many strengths and strategies, she was capable of forming viable and extensive partnerships. This capability helped her to achieve success with her counseling program.

The counseling literature provided sensitizing concepts for the study. Over the past few years, there has been a call for school counselors to redefine and expand their roles (Anderson \& Reiter, 1995; House \& Martin, 1998; Napierkowski \& Parsons, 1995; Paisley \& Borders, 1995). They have been admonished to assume a more activist role and move from a peripheral to a central position (Osborne et al., 1998; Sandhu \& Portes, 1995) in the interest of creating a climate conducive to student learning (Kaplan \& Geoffroy, 1990). Building and maintaining partnerships is one way that counselors can assume the mantle of educational leadership within their schools. In this article, we examine three strategies an exemplary school counselor used in creating partnerships. 


\section{Method}

\section{The Counselor and Context}

Claudia Vangstad began her career as a physical education teacher, but she had subsequently been a school counselor for 13 years, 6 years in her current school of 450 students. Changes in the school had begun just before her coming, but change escalated because of her activities. Vangstad's programs helped to foster change. She was the hub of a wheel that included multiple partnerships, built with one individual at a time, mostly in a quiet, persistent, and understated manner.

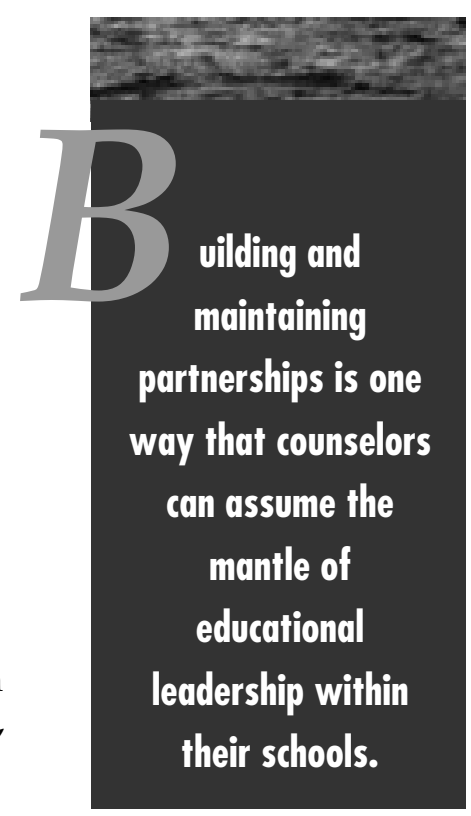

believed that all constituents in the school were potential partners, and she therefore worked to create partnerships with all of them. Second, she talked a language that everyone could understand-the language of problem solving. Finally, she used her counseling skills to solve problems where they occurred.

\section{Strategy 1: Create Partnerships with} All Constituents

\section{Partnership with the principal. Vangstad} believed that the most important partnership for a counselor is with the principal. Failure to establish that working

Vangstad's elementary school was located in a small town of approximately 5000 in the Pacific Northwest. The scenic coastal mountains surrounding the area provided a contrast to the difficult economic circumstances in much of the community, hit hard by the decline of the lumber industry and recent flooding. Drugs were a high-profile problem, particularly methamphetamine, and parental substance use fed domestic violence and neglect of children.

Before Vangstad established her guidance program, playground and classroom rage paralleled community stress. Fights-often bloody-erupted easily. Children's language was rough and inflammatory. Recess supervision was difficult, and children felt unsafe. School personnel, challenged by students' behavior, responded with power-assertive discipline. Teacher morale was low. Teachers sent a steady stream of hard-to-manage children to the principal's office. Negative teachers led the faculty, and teachers exacerbated the tense situation with negative talk about students and each other.

\section{Research Design and Procedure}

The study was ethnographic, describing and interpreting a school context, in this case (Creswell, 1998). We immersed ourselves in the counselor's school and community, seeking to discover what changes had occurred and what had provoked the transformations. Systematically, we interviewed school personnel and other members of the community. Later, audiotapes were transcribed and all data analyzed for themes and for transformational occurrences, using a constant comparative method of analysis (Glaser \& Strauss, 1967).

\section{Strategies to Create Partnerships}

As we studied Vangstad within the context of her school, three important strategies emerged as ways in which she used her capability to create partnerships. First, she relationship could easily undermine the counseling program. Even during her initial interview with the principal, Vangstad began to create this working relationship. She used open and direct communication. Vangstad commented as follows:

I interviewed him to make sure I got what I wanted. I told him, "I know what makes behavior worse, and what makes it better. I'll be looking at the behavior of teachers, but yet I'll be the biggest advocate they have. But I'll be looking at changing the teachers' behavior so that the child has an environment to change in."

Over time, mutual respect and support evolved between them. Vangstad's principal was her main personal and professional support: "I can go to him and ask, 'What do I do about this?' And if there's anyone to tell a secret to, truly confidential-my feelings, perceptions, it will be him." She added,

He has common sense, different ideas. He might disagree with something I propose and come up with another idea. Or let's say he wants to suspend a kid. I say, "OK. Let me throw this at you. What if we do something else instead of suspending this time." And he will think about it and go, "All right. We'll try it this time."

She in turn provided support for him. Vangstad said that she was "someone he can talk to." The principal said that in the counselor he found "a kindred spirit." The twoway support forged a powerful partnership.

The new partners developed a respect for each other's competencies. The principal did not burden Vangstad with the administrative and clerical duties that too frequently and inappropriately dominate a school counselor's life. Instead, the principal allowed her to apply her special school counselor expertise and personal strengths. 
Partnerships enhance the ability to influence. Because of their partnership, the principal began to change his view of how to deal with "problem students." Before Vangstad's arrival, he had, with reluctance and severe misgivings, used a paddle with unruly children. Because of Vangstad's influence, the "old" approach to children gave way to non-punitive methods. The principal said, "I realized children needed counseling, not just punishment." He kept the paddle on his office wall to remind himself of how he used to respond.

Their differing genders, personal styles, professional training, and ways of relating gave the principal and counselor balance as a team, and their differences helped to deflect the perception that they were a tooforceful, monolithic team. Their administrator/non-administrator alliance was also effective in helping them to stay alert to the complex dynamics of the system being transformed. Each allowed the other to vent, discuss, propose strategies, and think aloud. Built on mutual respect and trust, the working partnership of the principal and the counselor contributed needed support for the school counseling program.

Partnerships with teachers. With teachers, Vangstad worked strategically to develop rapport with detractors. The effect of such relationship building, one teacher at a time, appears not only to have developed support for her work, but also to have changed the school culture qualitatively over time. An itinerant teacher appreciated Vangstad: "Whenever you bring up an issue, she keeps notes. I am only in the building one day each week. But when I come back, she remembers it. She does something about it. That's a very critical follow-through." This same teacher observed counselor-teacher collaboration: "Did you notice when that teacher asked Claudia to call the parent? I don't know the situation, but they were working together."

Vangstad took seriously her role as consultant to teachers, with the goal of helping students learn better. Instead of focusing on "fixing the child," she spent time in classrooms observing and often offering gentle suggestions to teachers for altering ineffective communication patterns. Grounded in her training as a counselor, she taught teachers to discipline with respect, not punitively. Teachers began to look to her for guidance, trying new strategies and celebrating improvements. One teacher said, "She taught me how to put the responsibility on the kid." Another said, "When I first came, I remember sending kids to the office all the time. I haven't sent anyone this year."

We interviewed a teacher who had once received a negative evaluation because of classroom management. Vangstad had helped her in two ways. First, she had focused on her strengths; second, she had explored what the teacher had done to solve the problem.

A third way Vangstad helped teachers was with her wide range of supportive behaviors. One teacher commented about these: "Claudia does all the telephone calling. She is kind of a universal person, a third party. It's nice for teachers who have trouble in the classroom to have someone to talk to. Like I have one little girl in my class who still wets the bed. I'd rather have Claudia deal with that. She has training to talk to her parents. She'll come in and sit with me during a parent conference. She can fend off stuff that you feel threatened about."
Partnerships with teacher assistants. Probably the counselor's most remarkable bridge-building occurred with the teaching assistants. They were included in the process of change and were strategically empowered in their classroom and playground responsibilities. An assistant testified to the counselor's effect on her new roles:

\begin{abstract}
"I pay more attention to the children. I try to find out their backgrounds, see what they need. Some need more love than others to reassure them that we do care about them, and that if they have a problem, they can come to us. There's a way to do this, with our voice. If they're screaming and hollering, even if you feel like blowing up, keep your cool, and that will help sometimes calm a child down. When Claudia first came here, I thought, do we really need a counselor? Now I could eat those words."
\end{abstract}

The assistants seemed to be among her most staunch supporters. One assistant said, "She has really taken us as a staff and turned us around."

Partnerships with cooks. Vangstad did not stop with bridges just to the principal, faculty, and teaching assistants; she also involved the cooks in the cafeteria. She alerted them to children in need of affirmation so that the cooks could take special notice of them in breakfast and lunch lines. The cooks complimented children when they wore new clothing from the Dress-a-Child program, 
which Vangstad and the student council organized annually. When new children began attending the school, she introduced them to the cooks, who made them feel welcome at mealtime.

Partnerships with parents. Vangstad developed partnerships with parents as well, although, as one teacher said, "It took a while for the parents to be receptive. Now they like their kids doing things." Some of her actions were meant to engage parents with the school. An assistant said, "She has brought the parents up here and let them help. Now they're feeling more comfortable. They can walk through the front door and not feel so alienated."

The counselor kept the focus on the children, helping some parents with problem-solving suggestions for behavior management at home, while giving problemsolving attention to their children at school. A parent said, "My son was a conflict manager as a fifth grader. He really learned some skills in dealing with his brother. They don't have similar interests; they have to negotiate." Another parent, whose son was quiet and shy, said, "It built up his self-confidence being in that program." Even classroom teachers had been helped with their parenting: "She taught us on the faculty to deal with our own kids. It kind of rubs off if you're around her very much and you understand her philosophy and how she handles kids." A teaching assistant said, "I've started picking up the language. At home I say now, 'What's the problem? What would make the problem worse?' It just sort of permeates the whole place."

\section{Strategy \#2: Talk a Language That Everyone} Understands

Vangstad created partnerships through her teaching of a common language. Vangstad was unrelenting in teaching everyone in the school the language of problem solving so that all could converse using familiar terms (Littrell \& Peterson, in press). Vangstad's jargon-free approach had discernable steps that could be mastered even by very young children (Watzlawick, Weakland, \& Fisch, 1974). Problem-solving language permeated the school.

The widespread use of problem-solving language benefited the school personnel by uniting everyone involved. The problem-solving language avoided the pitfalls of "foreign" languages often found in packaged guidance programs-languages which remain the exclusive domain of counselors and which are often avoided by teachers. It was also not a behavioral language with terms such as "reinforcements" and "rewards," which make sense to some, but repel others.

One teacher said, "Problem solving is definitely Claudia's mode. If something doesn't work, try something else. Why blunder in the same old path if it's not working. I think it's something I had to develop." Another teacher reflected on the ultimate goal of counseling, "Claudia works one-on-one to help them understand their problems and solve them themselves so they don't need her."

Strategy \#3: Solve Problems Where They Occur

Vangstad's third strategy in building partnerships was to solve problems where they occurred. Most problems at school occurred in classrooms or on the playgrounds. Vangstad worked at those sites, with the parties involved, rather than in her office.

Playgrounds. In response to the dangerous playground behaviors, Vangstad forged important partnerships by altering "playground duty." Vangstad was instrumental in designating aides as teaching assistants, who then replaced teachers as playground supervisors. In addition, students in the older grades with behavior problems were given clipboards and trained as "conflict managers" for primary-level recesses. The counselor, conflict managers, and teaching assistants all became partners in improving the atmosphere of the playground. One teacher said, "She teaches the conflict managers problem-solving skills. They have to be role models. There's a lot less cussing. Kids are thinking more."

Classrooms. Whole-classroom interventions are a hallmark of school counseling, especially at the elementary school level. Teachers credited Vangstad's frequent and systematic presentations about problem solving as being crucial in changing the school climate: "All kids get it, so they can remind each other. Vangstad can specialize for some classrooms, stop something before it gets huge, gives good ideas to the teachers, has one ear cocked." Another teacher said, "I like Mrs. Vangstad in there. She calms the kids down. Some teachers feel that's their time and they leave. I always stay and listen. I like to see how she relates to the kids." 


\section{Discussion}

Vangstad's three strategies for creating partnerships served her vision: a school where children are problem solvers (Littrell \& Peterson, 2001). Partnerships were important in their own right, but they also helped create a school where her vision could be realized. Because Vangstad was capable of creating partnerships, numerous and varied constituents supported the counseling program. Because she worked in partnership with so many individuals, the counseling program affected the school much more significantly than a counselor acting alone could have.

School counselors wishing to enhance partnerships in their work can assess their current partnership-creating capability by answering questions based on Vangstad's three strategies:

1. Creating Partnerships with All Constituents

- Who are all the possible constituents of the school counseling program?

- To what extent have I reached out to all of them?

- What belief would I need to change to be more motivated to reach out to all constituents?

- What skills could I learn or use more often in reaching out?

2. Talking a Language That Everyone Understands

- Is the counseling program inaccessible to some because of esoteric language or professional jargon? Artificial or superficial language, such as might be found in "feelgood" programs? Mental health labels?

- To what extent do I use a language that invites people to be in partnership with me?

3. Solving Problems Where They Occur

- Am I invisible? Or do most people see me every day?

- What is the ratio of others seeking me out to my seeking them out?

- Does every teacher, staff member, student, and parent know me? Can I call all of them by name?

- Is my office where I do the bulk of my work, or am I interacting and offering my services wherever people are experiencing problems?

\section{References}

Anderson, R. S., \& Reiter, D. (1995). The indispensable counselor. The School Counselor, 42, 268-276.

Creswell, J. W. (1998). Qualitative inquiry and research design: Choosing among five traditions. Thousand Oaks, CA: Sage.

Glaser, B. G., \& Strauss, A. L. (1967). The discovery of grounded theory: Strategies for qualitative research. Chicago: Aldine.

House, R. M., \& Martin, P. J. (1998). Advocating for better futures for all students: A new vision for school counselors. Education, 119, 284-291.

Kaplan, L. S., \& Geoffroy, K. E. (1990). Enhancing the school climate: New opportunities for the counselor. The School Counselor, 38, 7-12.

Littrell, J. M., \& Peterson, J. S. (2001). Transforming the school culture: A model based on an exemplary counselor. Professional School Counseling, 4, 310-319.

Littrell, J. M., \& Peterson, J. S. (in press). Facilitating systemic change using the MRI problem-solving approach: One school's experience. Professional School Counseling.

Napierkowski, C. M., \& Parsons, R. D. (1995). Diffusion of innovation: Implementing changes in school counselor roles and functions. The School Counselor, 42, 364-369.

Osborne, J. L., Collison, B. B., House, R. M., Gray, L. A., Firth, J., \& Lou, M. (1998). Developing a social advocacy model for counselor education. Counselor Education \& Supervision, 37, 190-202.

Paisley, P. O., \& Borders, L. D. (1995). School counseling: An evolving specialty. Journal of Counseling \& Development, 74, 150-153.

Peterson, J. S., \& Littrell, J. M. (2000). A school counselor creates a problem-solving culture. International Journal of Educational Reform, 9, 311-320.

Sandhu, D. S., \& Portes, P. R. (1995). The proactive model of school counseling. International Journal for the Advancement of Counselling, $18,11-20$.

Watzlawick, P., Weakland, J. H., \& Fisch, R. (1974). Change: Principles of problem formulation and problem resolution. New York: W. W. Norton.

\section{Note}

We extend a special thanks to Claudia Vangstad for allowing us to chronicle many aspects of her work as an elementary school counselor. We also thank the administrators, faculty, staff, and students of the elementary school, as well as school board members and community leaders, for their generous cooperation during interviews. 